\title{
The Formation and Physiological Significance of Root Nodules in the Podocarpineae.
}

\author{
BY \\ ETHEL ROSE SPRATT, B.Sc., A.K.C. \\ Demonstrator in Botany at King's College, London.
}

With Plates LXXVII-LXXX.

THE assimilation of atmospheric nitrogen by plants, belonging to families other than the Leguminosae, which possess structures on their roots known as nodules, has long been recognized in the Cycadaceae, Elaeagnaceae, Alnus, and Podocarpus. Quite recently, too, Bottomley has shown that the root nodules of Myrica Gale are intimately associated with the fixation of free nitrogen.

Nobbe and Hiltner, in I899, demonstrated that the nodules of Podocarpus were active agents in the utilization of atmospheric nitrogen. In their experiments it was found impossible to cultivate plants of Podocarpus in the absence of the fungus which caused the nodule formation, but plants possessing nodules were grown for five years in quartz sand from which nitrogen was entirely absent, and during this period they remained perfectly healthy and grew well.

The earlier observers failed to demonstrate the presence of Bacteria in the nodules of these non-leguminous plants, but they found numerous hyphal-like structures in them, which they considered to be the hyphae of a mycorhizal fungus forming a symbiotic association with Podocarpus. Shibata described a mycelium, composed of non-septate hyphae possessing numerous nuclei, as being present in the cortical cells of the nodule. His investigations showed that these hyphae are eventually disorganized and absorbed, through the agency of a proteolytic ferment, by the host cells. These and similar observations in connexion with Alnus, Elazeagnus, and Myrica led to the idea that the formation of the nodules of non-leguminous plants was caused by the presence of an endophytic mycorhiza. More recent investigations, however, have shown this idea to be erroneous in some cases. Bottomley, in I909, isolated and grew the nitrogen-fixing organisms Psendomonas radicicola and Azotobacter from Cycas tubercles,

[Annals of Botany, Vol, XXVI. No. CrII. July, 1912.] 
and, in 1912, he has shown the nodules of Myrica Gale to be bacterial in origin. The author has described the root tubercles of Alnus and Elaeagnus as being caused by the infection of the root with a species of Psendomonas radicicola, which afterwards flourishes in the cortical cells of the nodule.

The first part of the present series of investigations was carried out with material of Podocarpus Totara, Podocarpus elongata, and Podocarpus chilina obtained from the Royal Botanical Gardens, Kew, at various seasons of the year. At the suggestion of Professor Bottomley, however, the observations were extended to comprise the whole of the group Podocarpineae; and through the kindness of the Director of the Royal Botanical Gardens, Kew, roots of Microcachrys tetragona, Dacrydium Franklini, Saxegothaea conspicua, and Phyllocladus trichomanoides were obtained.

In all the genera of the Podocarpineae numerous nodules are present on the small roots, along the sides of which they are arranged in two very definite rows, thus producing a beaded appearance (PI. LXXVII, Figs. i-5). In the four species of Podocarpus examined, P. Totara, P. elongata, P. chilina, and $P$. alpina, the nodules are almost spherical in shape, attaining a diameter of 0.8 to I mm., and are very symmetrically disposed along the two sides of the root (Fig. I). The nodules are very numerous, occurring quite close to one another along the whole length of the roots, which branch relatively infrequently. In general appearance the roots of Dacrydium Franklini resemble those of Podocarpus, but they branch somewhat more frequently; the nodules are smaller, only attaining a diameter of 0.54 to $0.68 \mathrm{~mm}$., and although they occur in two rows along the sides of the roots they are less regularly arranged (Fig. 2). The roots of Microcachrys tetragona are very fibrous, numerous very fine branches being produced, and along two sides of all these numerous small rootlets, minute nodules, with a diameter of 0.25 to $0.35 \mathrm{~mm}$., are arranged side by side in close proximity with one another (Fig. 5). In Saxegothaea conspicza the roots present a coralline appearance, being quite small, but so repeatedly branched that dense clusters are produced, and the roots bear two very closely packed rows of nodules, which are 0.4 to $0.5 \mathrm{~mm}$. across (Fig. 3). Phyllocladus trichomanoides has a much more straggling root, and the nodules are less numerous than in the other genera, but are present upon the small roots, where there are two rows, thus presenting the characteristic beaded appearance. In this genus they appear to be more widely separated from one another, and attain a diameter of about $0.5 \mathrm{~mm}$. (Fig. 4 ).

The roots and nodules of all these plants being quite small, it was found convenient to mount some of them whole for examination under the low power of the microscope, which immediately revealed the fact that the nodules in all the genera are endogenous in origin and each possesses a small but well-defined vascular strand, which is connected with the root- 
stele. In the material of Podocarpus obtained during the autumn and winter the surface of the nodules was always quite smooth, whilst in $P$. chilina, $P$. elongata, and $P$. Totara obtained in the spring the epidermal cells in a few nodules were growing out into hairs, and a few were covered with numerous fine non-septate hairs about the same length as the nodule. In $P$. alpina gathered in February a very large number of the nodules were clothed with a thick mantle of long hairs, some of which were quite three times as long as the nodules. The hairs were most abundant on nodules which were one year old, and which were, in many cases, attached to the roots in, or near, the regions where they themselves were producing roothairs, but they were also sometimes present on the nodules, which were two, three, or even four years old. In Microcachrys tetragona the surface of the nodules was generally quite smooth (Fig. 8), but occasionally small protuberances from the surface cells were visible. In Dacrydium Franklini, Saxegothaea conspicua, and Phyllocladus trichomanoides the production of hairs, in the spring, is a constant feature of all nodules which have completely emerged from the cortex of the root. It is, therefore, usually in the beginning of the second season's growth that practically all the surface cells of the nodules are capable of growing out to produce hairs, which radiate in all directions from the nodule (Figs. 6 and 7). In Dacrydium they attain a length about equal to that of the nodule in many cases, but sometimes they are longer; in Saxegothaea a thick mass of relatively long hairs covers the nodules, whilst in Phyllocladus they are very long and straggling.

These hairs are evidently comparable to root-hairs; they are nonseptate structures produced by the epidermal cells of the nodules, which are themselves modified roots. Like other root-hairs they are produced abundantly in the spring, whilst later in the year, in the autumn and winter, they collapse and eventually disappear. Any nodule which has reached maturity seems to be capable of producing these structures, but since they persist for very varying periods of time, nodules of diverse ages may be seen to possess hairs on their surface. When the nodule is more than two years old, however, they can distinctly be seen to be portions of the old hairs, which have remained attached to the nodules. They are evidently produced in response to certain environmental conditions in Podocarpus and Microcachrys, where it is only some of the nodules which produce these outgrowths, but in Dacrydium, Saxegothaea, and Phyllocladus there is a much greater tendency for the formation of hairs, their presence in the spring being characteristic of these genera. The frequent presence of root-hairs, not only on the roots but also on the nodules in all the genera of the Podocarpineae, precludes their association with a mycorhizal fungus.

In order to ascertain whether there were any Bacteria present in the nodules, some were removed from the roots, carefully washed with distilled 
water, then crushed on a slide, and the material so obtained allowed to dry. This was then stained with Ziel's carbol fuchsin or aniline gentian violet, and subsequent microscopical examination revealed the presence of numerous small rod-shaped Bacteria. These organisms were apparently identical with the Pseudomonas radicicola found in the root nodules of leguminous plants and also the Cycadaceae, Elaeagnaceae, Alnzus, and Myrica. Many of them contained two or three minute, spherical, densely staining bodies, which are so characteristic of that organism.

For further investigation with regard to the nature and growth of this organism, the exterior of some nodules from the Podocarpus roots was sterilized by placing them for about two minutes in a sterilizing fluid of the following composition :

$$
\begin{aligned}
& 2.5 \text { c.c. concentrated hydrochloric acid, } \\
& \text { I grm. mercuric chloride, } \\
& 500 \text { c.c. water. }
\end{aligned}
$$

They were then removed and thoroughly washed in distilled water, precautions being taken that all the instruments used were quite sterile. The nodules were then crushed, and their contents placed in a nutrient medium of the following composition:

I grm. saccharose or glucose,

$0.5 \mathrm{grm}$. acid potassium phosphate,

$0.02 \mathrm{grm}$. magnesium sulphate,

O.I grm. calcium carbonate,

roo c.c. distilled water.,

The solution was then incubated at a temperature of $28^{\circ} \mathrm{C}$. for two days, at the end of which period it had become quite cloudy owing to the rapid development of the rod-shaped Bacteria.

Pure cultures of this organism were also obtained on solid media, prepared by adding 2 per cent. agar-agar to the above nutrient solution. The colonies produced, after two days' incubation at $28^{\circ} \mathrm{C}$., were ovoid to circular in shape, entire, raised, shining, and viscous, with a diameter of 0.75 to $\mathrm{Imm}$. They were apparently characteristic colonies of Pseudomonas radicicola.

Since this organism so closely resembled, in its appearance and growth on nutrient media, species obtained from the nodules of legumes and the non-leguminous plants mentioned above, which are known to assimilate atmospheric nitrogen, 100 c.c. of the above nutrient solution containing saccharose was placed in each of four Erlenmeyer flasks, 300 c.c. capacity. To two of them, the controls, was added 2 c.c. of a liquid culture of the organism, obtained, as described above, from Podocarpas nodules. All the flasks were then sterilized by autoclaving, at a temperature of $140^{\circ} \mathrm{C}$. and 
a pressure of two and a half atmospheres, for ten minutes. After cooling, 2 c.c. of the same culture as had been added to the controls was used to inoculate each of the other two flasks. All were then incubated at $28^{\circ} \mathrm{C}$. for ten days. During this period the contents of the control flasks remained quite clear, whilst the others had become cloudy owing to the presence of a growth of a very slimy nature. The nitrogen content of the flasks was determined by the Kjeldahl method of analysis, with the following results:

$\begin{array}{ccc}\begin{array}{c}\text { Nitrogen found in } \\ \text { the control. }\end{array} & \begin{array}{c}\text { Nitrogen found in } \\ \text { the culture. }\end{array} & \begin{array}{c}\text { Gain in nitrogen } \\ \text { due to organism. }\end{array} \\ \mathrm{I} .06 \mathrm{~m} . \mathrm{grm} . & 3.72 \mathrm{~m} . \mathrm{grm} . & 2.66 \mathrm{~m} . \mathrm{grm} . \\ 0.93 \mathrm{~m} . \mathrm{grm} . & 3.46 \mathrm{~m} . \mathrm{grm} . & 2.53 \mathrm{~m} . \mathrm{grm} .\end{array}$

The increased nitrogen content of the solution in which growth took place can only have bcen produced by the activity of the living organisms obtained from the Podocarpus nodules and introduced into the media, and must have been caused by the utilization of the free nitrogen of the atmosphere by these organisms during the processes of metabolism. Hence it becomes evident why Hiltner was able to grow Podocarpus plants in pure sand, containing no nitrogen, provided nodules were present on the roots. The Bacteria in the nodules assimilate atmospheric nitrogen, and thus render it available to the Podocarpus plants.

Material used for sectionizing was fixed in either Flemming's or Bouin's fixative, or absolute alcohol. Microtomed sections were stained with Flemming's triple, Heidenhain's iron-haematoxylin, Ziel's carbol fuchsin, or Kiskalt's amyl gram stain with very satisfactory results.

The nodules of Podocarpus, Microcachrys, Dacrydium, Saxegothaea, and Phyllocladus, as of other non-leguminous plants, are modified lateral roots, being developed from the pericycle immediately opposite the protoxylem of the diarch root (Pl. LXXVIII, Figs. IO and II), and possessing a central stele (P1. LXXX, Fig. I7). Owing to some cells of the pericycle becoming meristematic (Pl. LXXVIII, Fig. Io, $a, b$ ), a small swelling is produced beneath the endodermis of the root. These cells continue to develop, and as the protuberance increases in size a plerome becomes differentiated (Fig. 10, $c$ and $d$ ), which later produces a vascular strand directly connected with the vascular cylinder of the root (Pl. LXXVIII, Figs. II and I2, and P1 LXXIX, Figs. I3 and I4): This structure gradually pushes its way through the cortex of the root and may become a lateral root, but very frequently, as indicated by the enormous number of nodules present on the roots, its growth is arrested, with the result that it produces a small almost spherical structure known as a nodule. This arrest in its development is caused by the infection of the young cells with the nitrogen-fixing organism Pseudomonas radicicola, before it emerges from the cortex of the root (Fig. 10). 
The Bacteria enter the cortex of the root by means of the root-hairs, in which they have frequently been seen, particularly in some young roots of Phyllocladius (Fig. 9). Having once penetrated the cell-wall and entered the hair, they multiply rapidly, producing a zooglea thread, exactly comparable to the infection threads of the Leguminoseae. The thread passes into a neighbouring cell, and subsequently numerous zooglea threads are produced which pass from cell to cell of the cortex (Figs. 9 and 16 ). When, however, a meristematic region arises in the neighbourhood of the Bacteria, they appear to be stimulated to further and more rapid development, and chemotactically attracted by the meristematic tissue, so that some of the infection threads penetrate into the young tissue (Fig. I0). Having once entered this new structure the Bacteria divide repeatedly, and the zooglea threads so produced ramify through the young cortical cells, causing their expansion, but arresting their further division, and consequently the immediate growth of the nodule.

A mature nodule possesses a small stele (Fig. I7), surrounded by a definite endodermis, the cells of which are slightly thickened on the outer side, although there is no evident radial dot, and many of them, as in the endodermis of the root, contain a deposit of tannin which renders them more apparent. In all the species of Podocarpus, where the nodules attain the greatest size in the group Podocarpineae, the nodular stele becomes distinctly diarch (Fig. I7); so also in Saxegothaea it usually becomes thus differentiated, but in Microcachrys and Phyllocladus the vascular strand is frequently very rudimentary, the xylem only consisting of two or three tracheides, around which are two or three layers of parenchymatous cells, and then an endodermis. The stele is continuous with that of the root and traverses about half the length of the nodule. The remaining nodular tissue is composed of parenchymatous cells, in which there is no differentiation of a meristematic zone, all the cells are similar, but the outermost layers after the nodule has emerged from the root for some time become slightly more compressed, and their walls become a little thicker, the outer ones eventually becoming slightly suberized (Figs. I I and I7). The outermost layer of cells of a mature nodule, like the epidermal cells of the roots, have the capacity of growing out to form hairs (Figs. 6 and 7). This they characteristically do in Dacrydium, Saxegothaea, and Phyllocladus in the spring of their second year, and it sometimes also occurs in Podocarpus and Microcachrys.

The cortical cells of both roots and nodules in all the genera appear to be traversed by numerous very narrow filaments. These, however, when stained with Kiskalt's amyl gram stain are seen to be composed of numerous rod-shaped Bacteria, obviously Pseudomonas radicicola, which are embedded in a mass of slime, forming a zooglea, and thus giving the appearance of a network of hyphae (Figs. I5 and 16). These threads are capable of pene- 
trating the cell-walls of the host tissue, and where the zooglea thread comes in contact with the cell-wall it widens out somewhat before passing through into the neighbouring cell. Expansion in this area is characteristic of infection threads produced by Pseudomonas radicicola in leguminous nodules. In the interior of the host cell some of the Bacteria become isolated from the infection threads and divide independently, forming groups of organisms. The threads vary considerably in width, even in the same nodule, sometimes being only a single chain of organisms, at others, especially in Podocarpus, as many as five, six, or even more are arranged across side by side, so as to form apparently one thread. The Bacteria are quite evident in the cells when the sections are treated with Flemming's triple stain or Heidenhain's iron-haematoxylin. They also respond, in the manner described by Harrison and Barlow as being characteristic of Psendomonas radicicola, to treatment with alcohol after. Gram's method of staining, that is, the aniline gentian violet is rapidly removed by ethyl alcohol, but not by amyl alcohol.

The zooglea threads are undoubtedly analogous to those present in leguminous nodules, and like them they appear to have an affinity for the nucleus of the host cell. Shibata described the nuclei of the cortical cells of Podocarpus nodules, which he said contained mycorhizal hyphae, as assuming an amoeboid form, and subsequently dividing directly until as many as eight nuclei were present in a single cell. The nuclei appear to be stimulated to activity when they become surrounded by a large number of Bacteria, for many instances have been seen, especially in Podocarpus, where more than one nucleus has been present in the cell containing. Bacteria. The increased number is evidently produced by amitosis, no. karyokinetic figures having been observed in such cells, but numerous elongated nuclei, and others in which the elongated structure is constricted in the centre and about to form two nuclei (Fig. I5). This effect of the presence of Bacteria around the nucleus of the host cell is quite comparable with that seen in the root-nodules of Elaeagnus, where the nuclei have been described by the author as becoming amoeboid and very irregular in shape, and then in some cases disintegrating.

As the season advances towards autumn further changes occur in the cortical cells of both root and nodules in all the genera. The cytoplasm and nuclei are gradually used up in the deposition of numerous cellulose bars on the walls of the cells, which gives them a scalariformly striated appearance, and assists in keeping them distended. The Bacteria tend to migrate from these cells, which appear first in isolated positions and thus become quite devoid of living contents. Gradually, however, almost the whole of the parenchymatous cortex, except the two or three outermost layers, becomes transformed into this water-storage tissue, and here the Bacteria continue to live in a quiescent state through the winter, until 
environmental conditions are again favourable for their activity, and also that of the host plant (Figs. II, I2, and I6).

The following spring, in the nodules of all the genera of the Podocarpineae examined, some of the cells immediately below the endodermis at the apex of the vascular strand of the nodule become meristematic (Fig. 12). A rapid formation of new tissue ensues in the centre of the nodule, pushing out and crushing the old water-storage tissue, which now readily collapses. The formation of new tissue beneath the endodermis causes the rupture of the latter, but later, when the rapid cell division ceases, a new endodermis is differentiated around the apex of the stele (Fig. 13). The Bacteria resume their activity and are stimulated to produce numerous infection threads, which penetrate into the newly formed cortical cells (Fig. I3). In this way living, active cortical cells are produced inside the old tissue of the nodule, which now forms a protective covering around the new nodule. This formation of a meristematic zone at the apex of the vascular cylinder, and the consequent production of new internal tissue, recurs year after year, so that a number of successive protective layers are formed around the active cortical cells by the annual displacement and collapse of the tissue formed the previous year (Fig. 14). The outermost zone in all the nodules always remains intact, being composed of a few layers of cells which are part of the first year's growth. It is this zone which has the capacity for producing hairs if occasion arises. The tissue produced in succeeding years becomes very crushed, and often, as in Microcachrys and Saxegothaea, almost obliterated, except at the base, just around the vascular strand, where the annual additions are always apparent.

In Saxegothaea conspicua, where the branching of the root is extremely prolific and the nodules are produced side by side in very close proximity to one another, the nodules have frequently been observed to branch (Figs. 7,18 , and 19). In the spring, when the meristematic zone arises at the apex of the vascular strand, bifurcation of the zone takes place (Fig. I 8), with the result that the nodule at first appears to have a branched stele; but later a distinct zone of cortical cells is produced by the apex of each branch of the stele. In this way two new cortical zones centred round a portion of the stele are produced inside the original nodule (Fig. I9), and these, at first, compress the tissue formed the previous year or years, and by their united activities eventually break through it. The tissue of the original nodule thus becomes ruptured and later is cast off; the two nodules produced in its place are each complete, independent structures, which subsequently develop according to the usual method described above. The capacity which the nodules in this genus have for branching gives the root its characteristic coralline, rather than beaded, appearance, a very large number of nodules being produced around the root eventually by their 
bifurcation. The rupture and subsequent shedding of the old outer nodular tissue when two nodules are produced in place of the old ones also adds to the possibilities of hair production by the surface cells. The old protecting layers having disappeared, the outer cells of the new nodules can, on reaching maturity, grow out into these structures. This explains the apparently more constant appearance of hairs on the nodules of Saxegothaea than on those of the other genera, because, on any portion, this method of branching makes it probable that there will be many nodules present which are only one year old, and which will probably be sending out hairs.

In their method of growth the nodules of the Podocarpineae differ from all other root nodules with which they are associated. The leguminous nodules are annual structures and are not modified roots, and the nonleguminous nodules of the Cycadaceae, Elaeagnaceae, Alnus, and Myrica are modified roots with a perennial habit, each possessing an apical meristematic region, by means of which their growth is continued from year to year. The nodules of the Podocarpineae, although perennial modified roots like the latter, are unique in having no persistent meristematic zone, the tissue definitely functioning for one year only. The formation of new tissue is always endogenous in this group, a new nodule being formed inside the old one year after year, whilst in the other non-leguminous nodules the growth is continued at the apex.

The nodules of the Podocarpineae are typically simple structures, whilst those of other non-leguminous plants are characteristically branched. The bifurcation of the nodule which occurs in Saxegothaea, as described above, recalls the branched nodules of the Cycadaceae, Elaeagnaceae, and Alnus, but in these there is no breaking through of old tissue; this latter occurs in Myrica, when the stele continues its growth and eventually penetrates the nodule, emerging as a small root. There is, however, no other known case where the original nodule, by branching, becomes replaced, as it does in Saxegothaea, by two apparently simple nodules.

The outer zones of dead empty cells in the old nodules provide a suitable substratum for the development of various Fungi, and in Podocarpus one sometimes finds true fungal hyphae in these cells. Some of these have probably been described by other observers, and may, indeed, as they suggest, be of a mycorhizal nature, forming a symbiotic association with the roots of the plant, but they are evidently not concerned with the formation of the nodules. This conclusion is supported by the production of roothairs on the nodules at the beginning of their second year's growth, which sometimes occurs in Podocarpus Totara, Podocarpus elongata, Podocarpus Chilina, and Microcachrys tetragona, usually occurs in Podocarpus alpina, and always occurs in Dacrydium Franklini, Saxegothaea conspicua, and Phyllocladus trichomanoides. Shibata, however, does not suggest that the fungus he describes causes the formation of the nodules, because he remarks 
that they may attain their full size even when they are not infected with it.

In the old roots there is a formation of periderm (Fig. I4), the phellogen arising immediately outside the endodermis, so that when this takes place the whole of the cortex is thrown off, amongst which are some cells containing Bacteria. This, however, does not usually occur until the root is two or three years old, by which time the formation of new nodules has ceased in this region, and the old ones already have a supply of organisms for the infection of their new cells.

These investigations entirely support the theory that the root nodules of Podocarpus are actively concerned in the assimilation of atmospheric nitrogen, not, however, primarily owing to the presence of a mycorhizal fungus, but to their symbiotic association with a nitrogen-fixing bacterium. This not only occurs in all the species of Podocarpus examined, but also in Microcachrys, Dacrydium, Saxegothaea, and Phyllocladus, four other genera of the Podocarpineae. The production of nodules on the roots is thus a constant feature throughout the Podocarpineae, their development and morphology being in every case of the same characteristic type, and they are always inhabited by apparently the same organism. This organism is morphologically and physiologically identical with Pseudomonas radicicola found in the nodules of the Leguminosae, Cycadaceae, Elaeagnaceae, Alnuts, and Myrica. This organism enters the roots of plants of the Podocarpineae, and the infection of the meristematic cells of a young lateral root causes its transformation into the structure known as a nodule. In this tissue the Bacteria multiply very rapidly, and in their growth they have been shown to utilize the free nitrogen of the atmosphere, so that by their development in the nodules attached to the plant they are rendering that vast store of food material available, and enabling the plant to grow even under circumstances which exclude all other nitrogen supply.

The division of the Coniferales known as the Podocarpineae are inhabitants of the southern hemisphere, principally Australia. The dominant genus Podocarpus has been considered related to the Araucarineae, through Dacrydium and Saxegothaea, on certain morphological grounds, and this association is supported by the common and peculiar geographical distribution of the two groups. Tison supports this idea, from the behaviour of the two systems of vascular bundles found in the megasporophyll, but he also says that Podocarpus and Saxegothaea are very definitely related through Microcachrys. There are many arguments against a union of the Podocarpineae and the Araucarineae, but all the morphological work on the various parts of the plants indicates that Saxegothaea and Podocarpus are the most widely separated of all the genera placed in the Podocarpineae, and Dacrydium and Microcachrys form connecting links between them. This conclusion is supported by the morphology of the root nodules in this 
group, those of Podocarpus and Microcachrys being most nearly alike, differing only in size, whilst Dacrydium resembles Saxegothaea in the characteristic prolific formation of hairs, and Saxegothaea differs from all the rest in the extremely frequent branching not only of the root but also of the nodules.

The genus Phyllocladus has led to considerable discussion as to its relationships, since it possesses some of the characters of both groups of the Taxaceae, namely, the Taxineae and the Podocarpineae, and consequently may belong to either of these groups, or it may be an intermediate group between them. Young has summarized the characters which it possesses that are common to these groups respectively, and has decided that the features which relate it to the Podocarpineae are more fundamental than those relating it to the Taxineae, and are also too fundamental to admit of its being placed in an intermediate group. The presence of root nodules, indicating the capability of the root to form a symbiotic association with the nitrogen-fixing organism Pseudomonas radicicola, in Phyllocladus, as well as in all the other genera of the Podocarpineae, is an additional character relating Phyllocladus with this group.

In conclusion, I wish to thank the Director of the Royal Botanic Gardens, Kew, for supplying the material necessary for my work, and also Professor W. B. Bottomley for his suggestions and kindness during the progress of these investigations, which have been carried out in his laboratory at King's College, London.

\section{SUMMARY,}

I. Root nodules are present in all the genera of the Podocarpineae examined, namely, Podocarpus, Microcachrys, Dacrydium, Saxegothaea, and Phyllocladus.

2. The nodules are modified lateral roots. They are perennial unbranched structures, except in Saxegothaea, where bifurcation frequently occurs.

3. The outer layer of cells in the nodules is capable of producing nonseptate hairs at the beginning of the second year's growth in all the genera, but their presence is characteristic of the nodules Dacrydium, Saxegothaea, and Phyllocladus.

4. The nitrogen-fixing organism Pseudomonas radicicola penetrates a root-hair and from thence enters the cortex of the root, where it propagates itself.

5. The nodules, in all the genera, are produced by the infection of the meristematic tissue of the young root, before it emerges from the cortex of the parent root, by Pseudomonas radicicola.

6. A mature nodule is traversed for about half its length by a small 
stele. In Podocarpus and Saxegothaea the stele is diarch; but it may remain more rudimentary, as in the small nodules of Microcachrys, where frequently only two or three tracheides are present. There is always an endodermis.

7. There is no differentiation of a meristematic zone in the cortical tissue. In this respect the nodules of the Podocarpineae differ from the nodules of all the other non-leguminous plants with which they associated.

8. The majority of the cortical cells of the root and nodules eventually become water-storage cells, and in some of these the Bacteria remain quiescent during the winter.

9. The Bacteria produce a very definite zooglea in the cells, and in these slime threads pass from cell to cell.

IO. The nuclei of the host cells, in Podocarpus, are stimulated by the presence of the zooglea around them to elongate and then divide amitotically, so that several nuclei are frequently present in one cell.

II. In the spring the cells immediately below the endodermis at the apex of the nodular stele become meristematic and produce new cortical cells in the interior of the old nodule.

I 2. Successive zones of collapsed tissue surround the new cortical cells of the nodule year by year.

I3. In Saxegothaea the meristematic tissue at the apex of the nodular stele frequently bifurcates before producing the new cortical cells, with the result that there are two centres of tissue formation and two new nodules are produced inside the old one, which is eventually ruptured and cast off.

I4. The outer empty cells in Podocarpus are sometimes inhabited by fungal hyphae, which may be of a mycorhizal nature.

I5. The Bacteria isolated from the nodules are found to be identical in structure, and growth in pure cultures, with Pseudomonas radicicola obtained from the root nodules of the Leguminosae, Cycadaceae, Elaeagnaceae, Alnus, and Myrica.

I6. When isolated from the nodule the organism is capable of assimilating atmospheric nitrogen when grown on suitable media, and consequently its presence is undoubtedly beneficial to the plants of the Podocarpineae, with which it is associated.

I7. The morphology of the nodules supports the theory that Podocarpus and Saxegothaea are the most widely divergent of the genera in the Podocarpineae, and that they are connected through Microcachrys and Dacrydium.

18. The presence of root nodules in Phyllocladus is additional evidence for regarding it as a member of the Podocarpineae rather than of the Taxineae, or a group intermediate between these two. 


\section{BIBLIOGRAPHY.}

Воттомцey, W. B.: The Cross Inoculation of the Nodule-forming Bacteria from Leguminous and Non-leguminous plants. Report, British Association, 1907.

: Some Effects of Nitrogen-fixing Bacteria on the Growth of Non-leguminous Plants. Proc. Roy. Soc. B., vol. lxrxi, 1909, p. 287.

: The Root-nodules of Myrica Gale. Ann. of Bot., Jan. Igra.

Coulter, J. M., and Chamberlain, C. J. : Morpbology of Gymnosperms. University of Chicago Press, Chicago, Illinois, rgio.

Harrison and Barlow: The Nodale Organism of the Legaminoseae. Proc. Roy. Soc. of Canada, Igo6.

Nobre and Hiltner: Die endotrophe Mykorrhiza von Poacarpus und ihre physiologische Bedentung. Landwirthsch. Versuchsst., Lief. i, 1899.

Osborn, T. G. B.: The Lateral Roots of Amyelon radicans, Will, and their Mycorhiza. Ann. of Bot., Igag.

Shibata, K. : Cytologische Studien über die endotrophen Mykorrhizen. Jahrb. f. wiss. Bot., xxsvii, 1903.

Spratt, E- R. : Some Observations on the Life-history of Anabaena Cycadeae. Ann. of Bot., I9II. : The Morphology of the Root-tabercles of Alnus and Elacagrins, and the Polymorphism of the Organism causing their Formation. Ann. of Bot, I 19.

Tison, A. : Sur le Saxegothaea. Lindl. Mem. Soc. Linn. Normandie, 23, Igog.

Young, M. S. : The Morphology of the Podocarpineae. Bot. Gaz., 1, igio.

\section{DESCRIPTION OF PLATES LXXVII-LXXX.}

Illustrating Miss Spratt's paper on the Root-nodules of the Podocarpineae.

In Figs. $6-8, r=$ root, $n=$ nodule, $s t=$ stele, $h=$ hairs, $a=$ young nodule, $b=$ nodule one year old, $c$ mo nodule two yea:s old, and $d=$ nodule several years old. Bacteria.

In Figs. 10-19, $x=$ xylem, $p h=$ phloem, $p=$ pericycle, $e=$ endodermis, $c=$ cortex, $b=$

\section{PLATE LXXVII.}

Fig. I. Root of Podocarpus Chilina with nodules. $\times 2$.

Fig. 2. Root of Dacrydium Franklini with nodules. $\times 2$.

Fig. 3. Root of Saxegothaca conspicua with nodules. $\times 2$.

Fig. 4. Root of Phyllocladus trichomanoides with nodules. $\times 2$.

Fig. 5. Root of Micracach rys tetragona with nodules. $\times 2$.

Fig. 6. Root and nodules of Dacrydium Franklini. $\times 60$.

Fig. 7. Root and nodules of Saxegothaea conspicua. $e=$ branched nodule. $\times 60$.

Fig. 8. Root and nodules of Microcachrys tetragora. $\times 60$.

\section{PLATE LXXVHI.}

Fig. 9. Root-hair and cortical cells of Phyllocladus trichomanoides, showing the infection with Pseudomonas radicicola. $b=$ Bacteria, i.t. $=$ infection thread, $r . k,=$ root hair, $e=$ epidermal cell of root. $\times 730$.

Fig. 10. Longitadinal section of a root of Podocarpus Totara with young nodales A, B, C, and D. if. $\mathrm{c}$ infection thread, $p l=$ plerome, $w=$ water-storage cell. $\times 105$. 


\section{Spratt.-Formation of Root Nodules in the Podocarpineae.}

Fig. Ir. Transverse section of a root of Podocarpus chilina.with a mature nodule attached. $p . x .=$ protoxylem, $s . x .=$ secondary rylem. $\times 105$.

Fig. I2. Longitndinal section of a root of Padocarpus elongata with a nodule at the beginning of its second year, showing the meristematic zone, nt.s., which will prodace the new cortical tissue of the nodule. $\times 105$.

\section{PLATE LXXIX.}

Fig. r3. Longitudinal section of a root of Padocarpus elongata with a nodule in the second year of its growth, when the new cortex hes been formed. n.c. $=$ newly formed cortex, a.c. $=$ old cortex. $\times$ I05.

Fig. I4. Longitndinal section of a root of Padocarpus chilina with a nodale several years old. $1=n e w$ tissue, $2,3,4,5=$ layers of tisste which formed the cortex of the nodule in preceding years, $c=$ cork. $\times$ ro5.

Fig. 15. Cortical cells of the nodule of Padocarpws Totara with Bacteria. i.t. $\Rightarrow$ infection threads, $n=$ nucleus of the host cell; $a, c$, and $d$ are nuclei in stuges of direct division. $\times 730$.

Fig. I6. Cortical cells of the root of Podocarpus Totara with Bacteria. i.t. = infection threads, $n=$ nuclens of host cell, $w=$ water-storage cell. $\times 730$.

\section{PLATE LXXX.}

Fig. 17. Transverse section of the root nodule of Padocarpus elongata. $\times 120$.

Fig. I 8. Longitudinal section of the root nodule of Saxegothaea conspicua, showing the branching of the meristematic zone. $c=$ cortex formed last year, $a=$ tissue formed the first year, stastele, mi.s. = meristematic zone, $h=$ hair. $\times$ I 20.

Fig. 19. Longitadinal section of the root nodule of Saxegothaea conspicua, showing two new nodules produced as the result of the branching of the meristem formed in the original nodule. $n \sim$ cortex of the new nodule, st $=$ stele, $a=$ old nodalar tissue being cast off. $\times 120$. 
Annals of Botany.

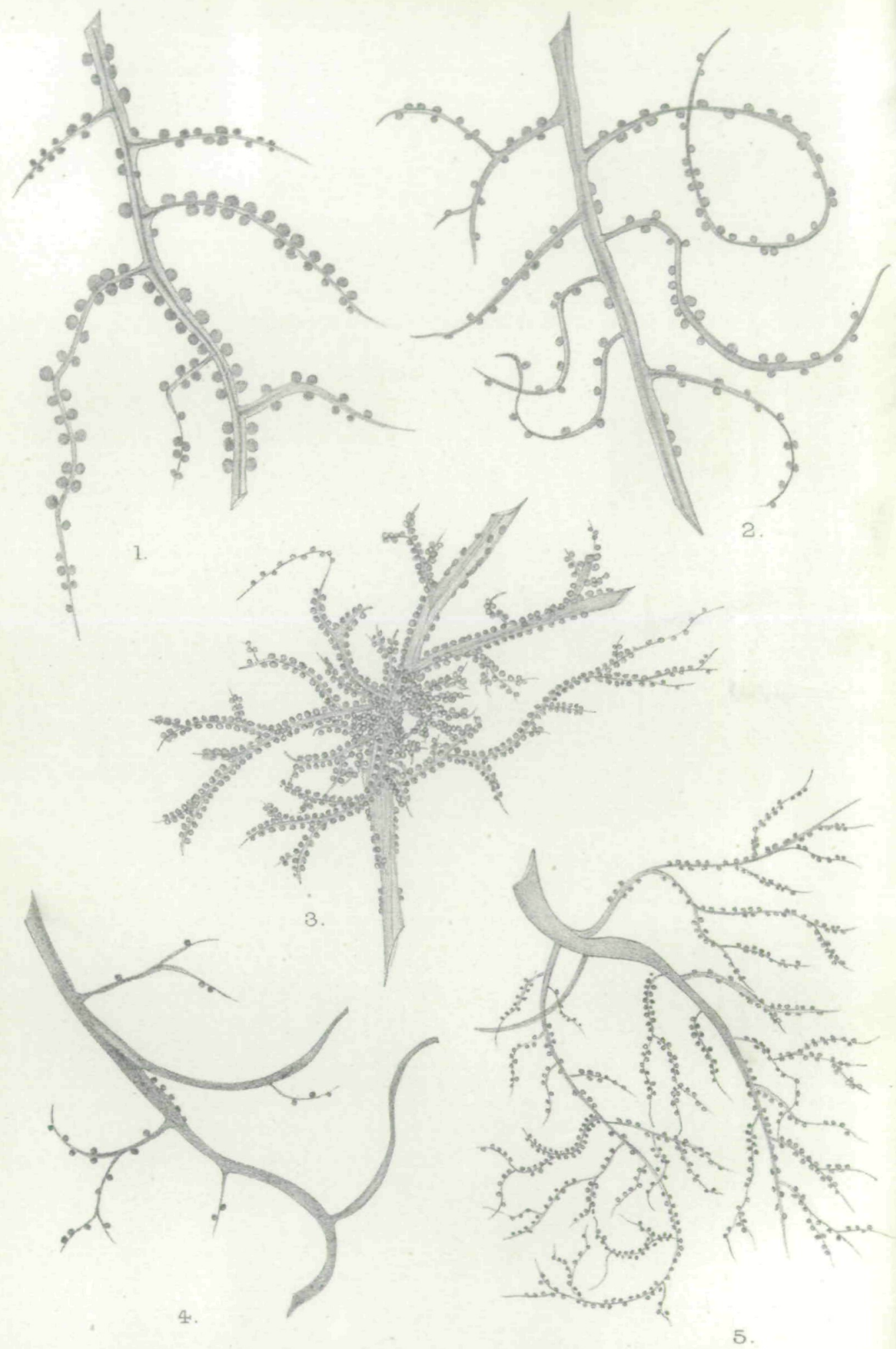

E.R.Spratt, det.
Vol. XXVI. PL IXXVII.

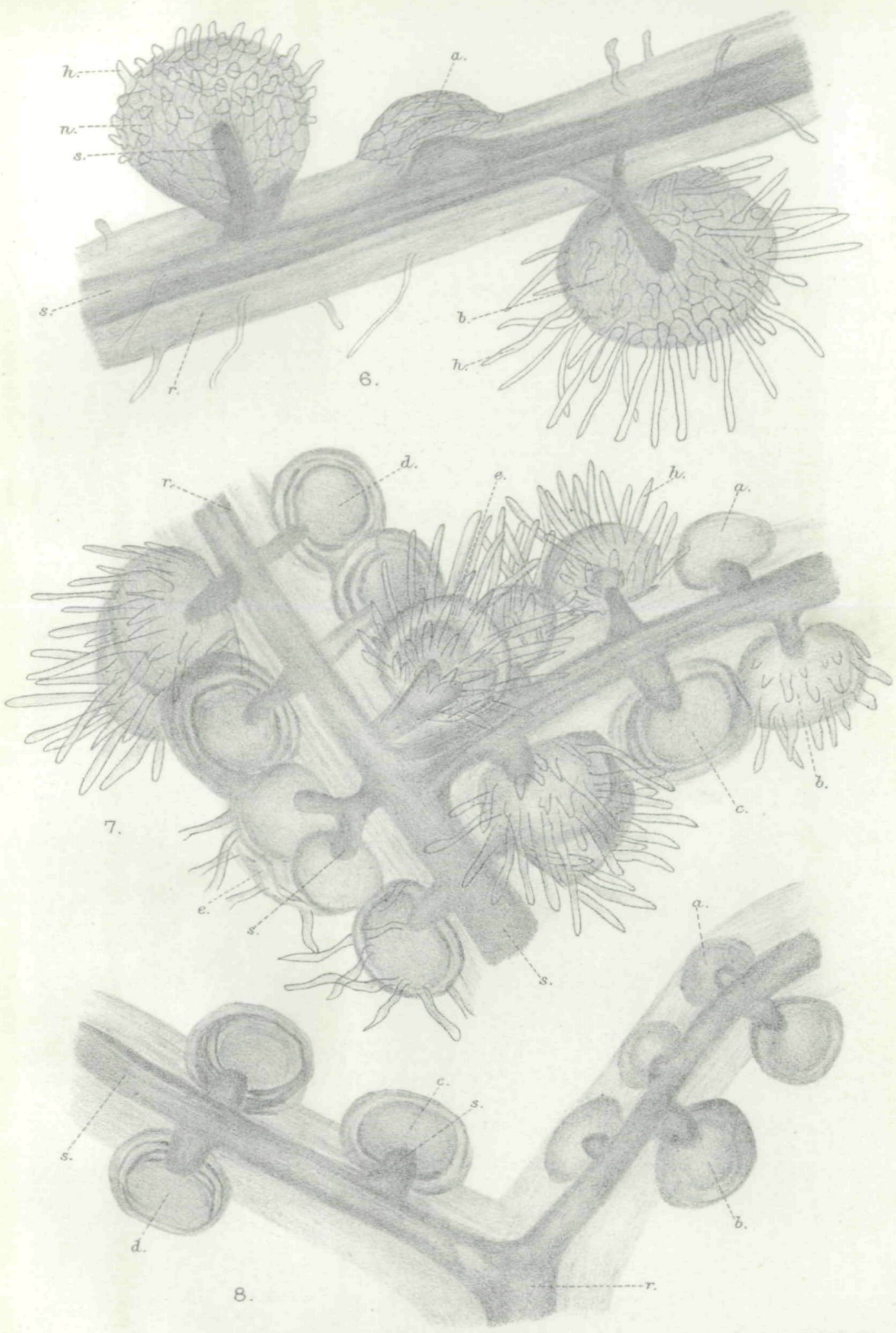


7oOHOS AN甘108

רoOHOS ANH 10

(700Hos AN1109 

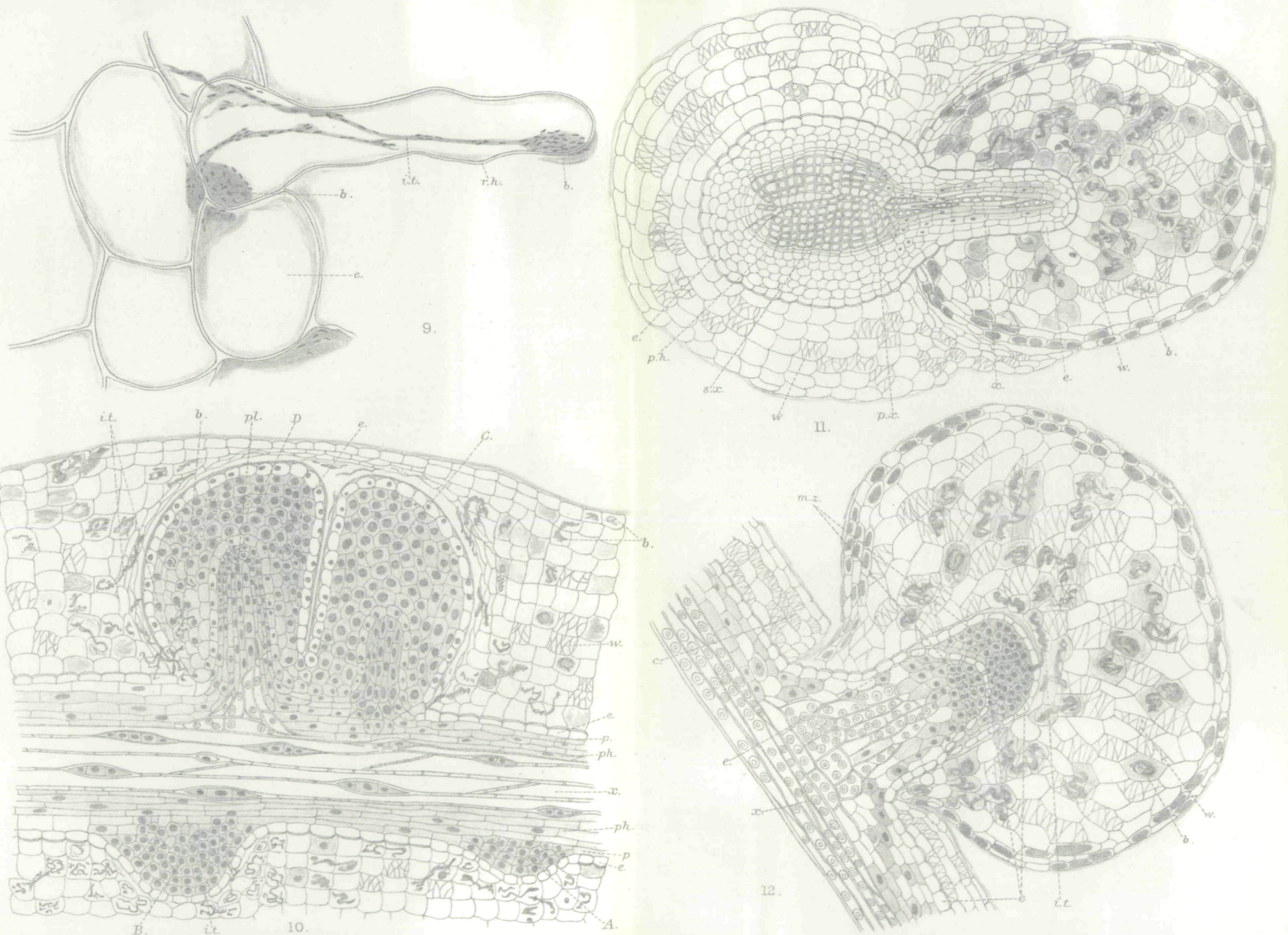

SPRATT- NODULES OF PODOCARPINEAE. 


$$
\ominus \Leftrightarrow
$$



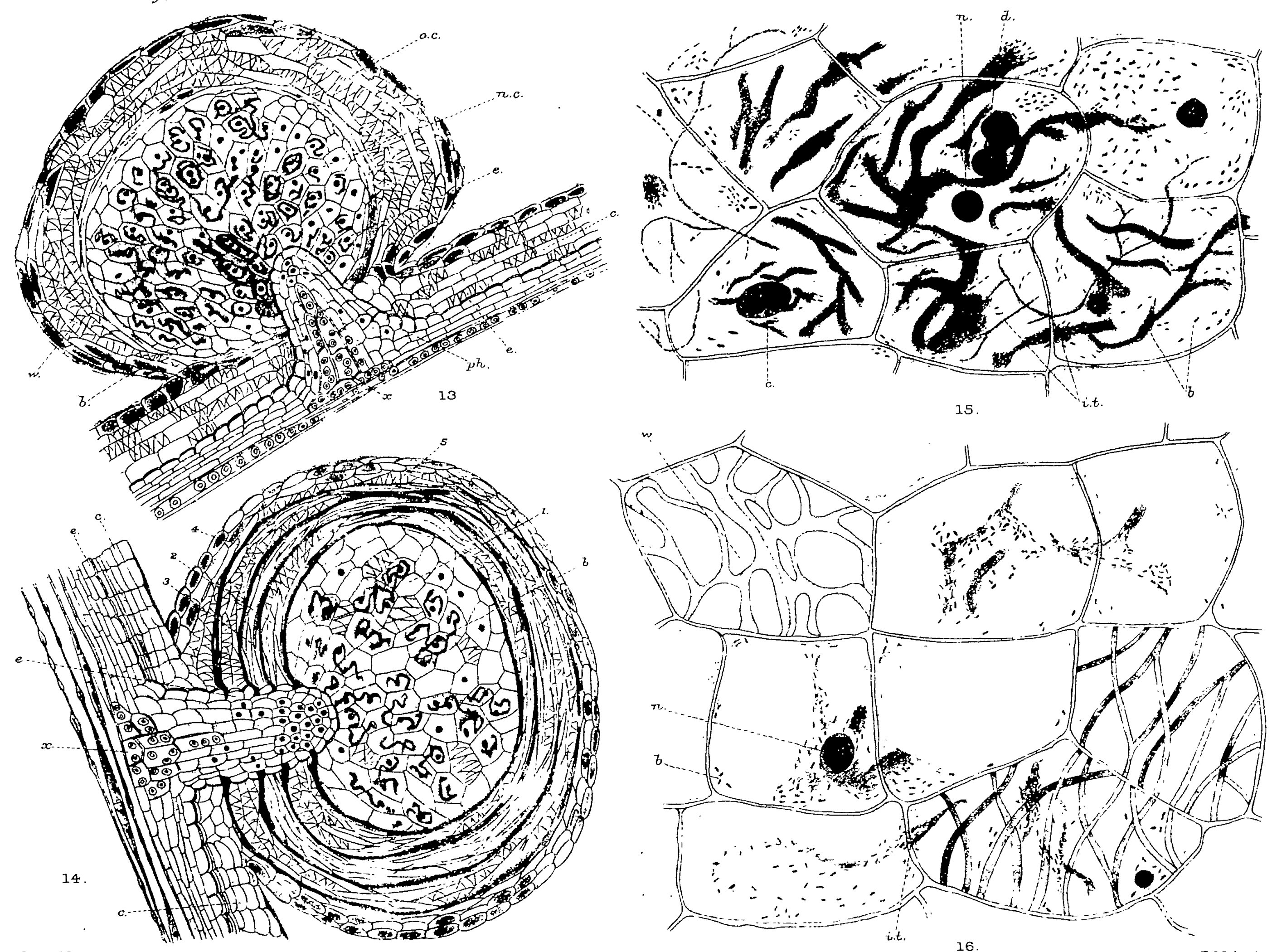


$$
=0
$$




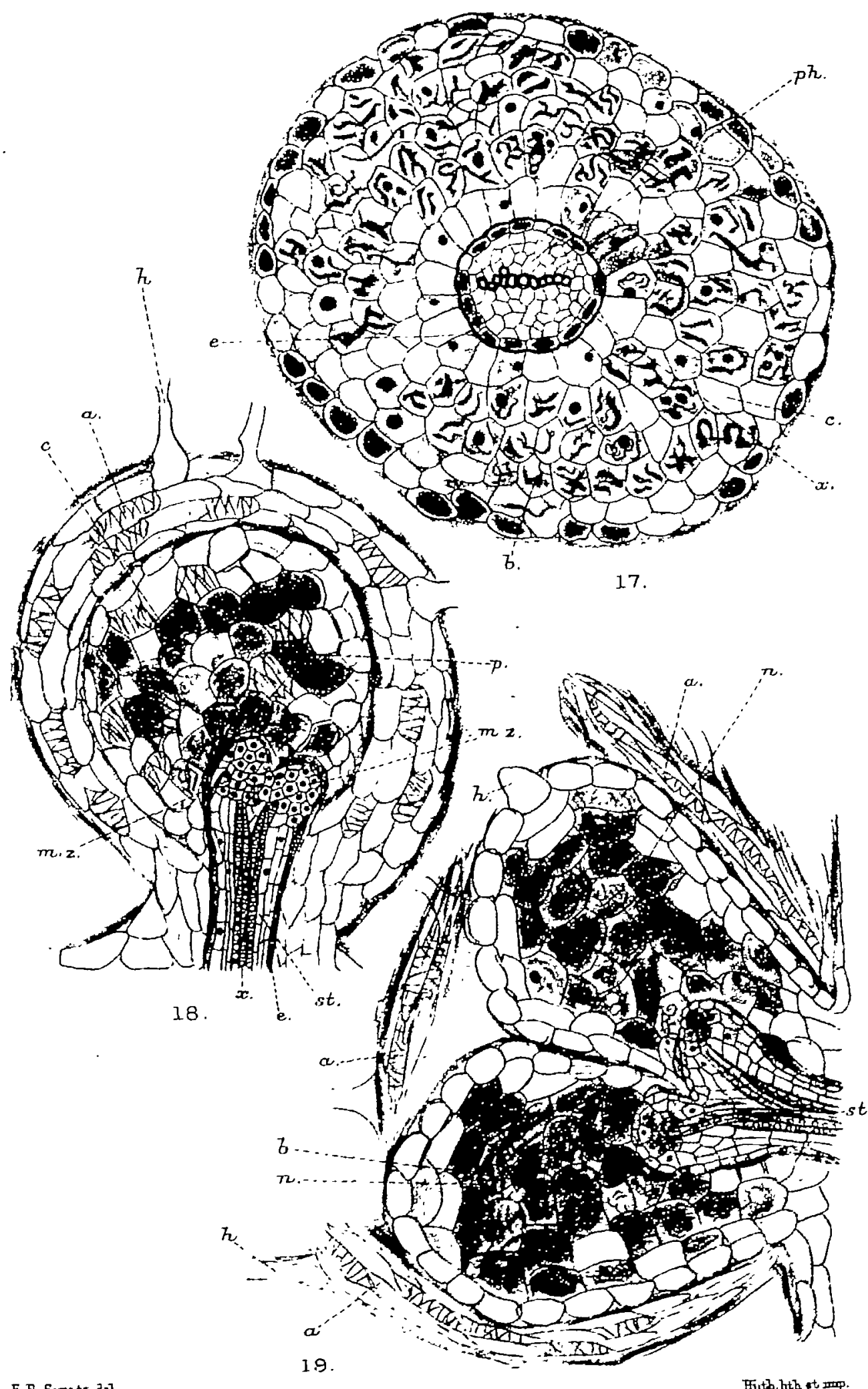




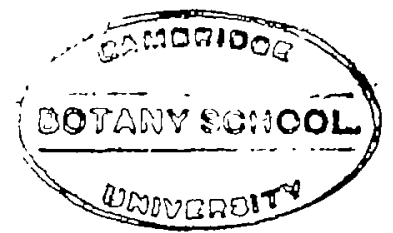

